Manuel Padilla Cruz

University of Seville

\title{
EVIDENTIAL PARTICIPLES AND EPISTEMIC VIGILANCE
}

Abstract: For communicated contents to be accepted by the audience, they have to pass the filters of epistemic vigilance mechanisms, which check the credibility and reliability of communicators and the information provided. Communicators may lack adequate evidence about the information they dispense. One of the ways to indicate to the audience that they are uncertain about some information (rather than to put their reputation as reliable speakers at risk) is to use participial adjectives, such as 'alleged' or 'suspected'. The chapter discusses the features of such adjectives and argues that they specialise for marking the speaker's epistemic stance towards the information communicated -a function they share with other evidentials. Unlike many other expressions denoting epistemic stance, however, they appear to be confined in their scope to the noun phrase in which they occur.

\section{Introduction}

This chapter focuses on a group of the so-called participial adjectives, which seem to modify heads of noun phrases in attributive position (Greenbaum and Quirk, 1993; Huddleston, 1993). As opposed to 
prototypical adjectives, participles like the English 'alleged' or 'suspected', or the Spanish 'supuesto' or 'presunto', do not contribute to the propositional content of assertions or claims by providing information about the properties or states of the head nouns they co-occur with. Instead, they work as indicators of the quality of the information communicated about the referent of that noun and the communicator's epistemic stance towards what she says.

In contrast to a variety of linguistic expressions signalling epistemic stance towards a whole proposition, the participles under analysis indicate whether a fragment of a proposition can be (dis)credited due to lack of adequate evidence at the time of speaking or writing. More specifically, these participles prevent the audience from definitively attributing the agency of or the responsibility for some event, action or state of affairs to the referent of the noun with which they co-occur, as well as from assigning a certain quality or condition to the referent of that noun. Consequently, the audience are entitled to assume that further evidence is required in order to attribute agency, responsibility or a condition to the nominal referent in the (near) future. To put it differently, the participial adjectives examined here caution the audience that they should not think that, when making a claim, the referent of a noun has carried out a certain action or that the state of affairs denoted by the noun actually holds true, even if responsibility for such action may subsequently be proved or the denoted state of affairs may 
subsequently be found out to hold true. Thus, informers seek to avoid derivation of erroneous implications and formation of unwarranted beliefs. Many of the actions performed in verbal communication are made evident by means of a variety of markers, particles, lexical items or formulaic or ritualised expressions. Comprehension of dispensed information may be facilitated when communicators indicate the relationships between different propositions and guide the audience to the expected cognitive effects (Sperber \& Wilson, 1986/1995; Wilson \& Sperber, 1993, 2002a, 2004). Expressions exhibiting the communicator's attitude(s) or feeling(s) towards what she says and expressions unveiling, or simply hinting, that the communicator (firmly) believes, does not believe or questions some information, or that she possesses or lacks sound evidence for it also aid interpretation. Stylistic choices, then, end up being fundamental for ensuring that the audience arrive at intended meaning and what is said achieves the expected effects. As part and parcel of the stylistic decisions that communicators constantly make, the participial adjectives under analysis are added to assertions or claims in an attempt to achieve optimal relevance and make the communicator's informative intention unambiguously manifest. This chapter begins by briefly illustrating some of the actions performed verbally in Section 2. Next, Section 3 exemplifies the variety of linguistic expressions guiding and constraining comprehension. Since among those expressions are the past participles alluded to, Section 4 will compare their features to those of prototypical participial adjectives, from which they 
differ in some morpho-syntactic aspects. Such differences suggest that those past participles make up a group that is specialised for a very specific function: assisting the audience in their interpretative task by indicating whether they can believe, put into question or discredit the information imparted on the basis of available evidence. By so doing, these participles share functions with other evidentials (Ifantidou, 2001), so here they will be labelled evidential participles. Finally, Section 5 discusses their functions and contribution to communication.

\section{Things we do with words}

Verbal communication is an incredibly complex activity wherewith and wherein a wide array of social and cognitive goals are pursued and fulfilled. The foundational works of Speech Act Theory (Austin, 1962; Searle, 1969) made it clear that utterances may not simply describe the world, but also perform actions in more or less direct or transparent ways. Among them are requesting goods or services (1), congratulating others on their achievements (2), complimenting them on, for instance, their appearance (3), or apologising for offences or trespasses (4): ${ }^{1}$

\footnotetext{
${ }^{1}$ See Norrick (1980) and Marandin (1987) for differences between compliments and congratulations.
} 
(1) Can/Could you (please) take this parcel to the post-office for me and send it?

(2) Excellent essay!

(3) I like your new hairdo.

(4) Sorry I am late!

Satisfactory accomplishment of those actions requires determining social distance, which interlocutor holds more power because of qualifications, skills, personal qualities or position within a particular institution, or if an action may involve some cost or benefit to the interlocutors, put them in a difficult position or contravene their sociality rights and sociality obligations (Brown \& Levinson, 1987; Spencer-Oatey, 2008). ${ }^{2}$ As a result, interlocutors constantly make choices regarding what to say and how to say it, and formulate utterances in such a way that they give sufficient clues about their desire to be considerate or to create, maintain, re-define or destroy social relationships in a particular situation (Arundale, 2006; Locher ,2006). The request in (1) could be rendered more indirectly if the speaker thought that going to the post-office might take the requestee a good while or if she wanted to avoid sounding too bossy because she had previously asked him other favours:

${ }^{2}$ Sociality rights and obligations are those social or personal expectancies or entitlements that individuals claim for themselves. Some of them are constantly negotiated, while others are culturally or situationally determined beforehand. Individuals expect those rights to be respected, so they have expectations which, if unsatisfied, may affect their social relationships (Spencer-Oatey, 2008). 
(5) a. Do you think you could take this parcel to the post-office and send it for me?

b. I was wondering whether the post-office might still be open.

Likewise, if a straightforward congratulation on an unequalled essay (2) was perceived as detached, the speaker could elaborate on the reasons why she praises it as a way of empathising with the hearer and making it clear that she intends to praise his work (Norrick, 1980; Marandin, 1987):

(6) Excellent essay! It addresses most of the current challenges in relevance-theoretic pragmatics.

Not knowing another person well may render complimenting risky, as the complimentee may think that the complimenter simply seeks to comply with rules of etiquette, is flattering or even making fun of him (Wolfson, 1983; Holmes \& Brown, 1987). That riskiness is avoided by means of a more indirect formulation which evidences that the complimenter has noticed a change in the complimentee but does not unveil her real opinion about it:

(7) It seems that you've been to the hairdresser's.

If a recurrent formula to apologise (4) is thought to sound insincere, the speaker may want to show true regret by adding the reasons for the apology:

(8) There was a huge traffic jam and I could not make it on time for class. Dispensing information other people might need or have an interest in impacts their set of beliefs. These may be altered by adducing evidence that certain facts or states of affairs hold or that some of them should be abandoned. Thus, people attempt to convince others of facts or states of 
affairs, to persuade them to do certain things or believe specific issues, or even to manipulate them.

Since information may be true or false, when imparting it individuals are normally interested in appearing competent -i.e. skilled communicators and knowledgeable about specific issues- and benevolent -i.e. reliable or trustworthy informers (Sperber, 1994). Grice (1975) himself captured the intuition that communicators are usually expected to tell the truth or that telling it is beneficial for communication in his 'Maxim of Quality'. 3 Benevolence causes speakers to indicate certainty or lack of evidence about information by means of various stylistic choices. For example, if an individual wants to communicate that it actually is or may be cloudy in Seville at a specific time, she can opt for any of the formulations below in order to present her degree of certainty or the kind of evidence she relies on:

(9) a. It is cloudy in Seville now.

b. It must be cloudy in Seville now.

c. It may be cloudy in Seville now.

d. It might be cloudy in Seville now.

e. They say that it could be cloudy in Seville now.

f. I have (just) heard that it is cloudy in Seville now.

\footnotetext{
${ }^{3}$ See Sperber \& Wilson (1986/1995), Wilson (1995) and Wilson \& Sperber (2002b) for arguments against this maxim and the cooperative principle.
} 


\section{Style and relevance}

Comprehension normally follows the path of least cognitive effort and maximum cognitive benefit. The human mind carries out a process of mutual parallel adjustment that mobilises a series of mechanisms or modules that perform a number of simultaneous tasks (Carston, 2002). Among them are decoding, inferring, mindreading, emotion-reading or assessing the veracity and reliability of information (Wilson, 2012). ${ }^{4}$ Decoding yields an organised set of conceptual representations (Sperber \& Wilson, 1986/1995, p. 72). Inference enables segmentation of sounds and identification of words, parsing and disambiguation of syntactic constituents, assignment of reference, adjustment of the conceptual content of some words, and recovery of ellipsed material. The output of these tasks is the lower-level explicature of an utterance, or a fully propositional form whose truthfulness or falsity can be verified.

Inference, mindreading and emotion-reading work jointly in order to construct a description of the speech act that the speaker is thought to accomplish, the attitude that she is considered to have towards what she says or her degree of certainty about it: the higher-level explicatures (Sperber \& Wilson, 1995, pp. 181-182). Finally, inference makes it possible to relate the content of an utterance to assumptions that the audience have evidence

\footnotetext{
${ }^{4}$ As opposed to cognitivists, relevance theory endorses the massive modularity thesis, which conceives of the human mind as a complex set of specialised and mandatory mechanisms.
} 
to think that the speaker expected them to supply-implicated premises-so as to arrive at an intended implicated content-implicated conclusions (Sperber \& Wilson, 1986/1995; Wilson \& Sperber, 2002a, 2004).

The fast pace at which these tasks are performed and psychological and physiological factors -e.g. tiredness, absent-mindedness, multi-tasking, drowsiness, etc.- often negatively affect their output. In fact, on many occasions the audience experience problems at disambiguating constituents, assigning reference or constructing higher-level explicatures, miss implicatures or arrive at unintended ones (Yus Ramos, 1999a, 1999b; Padilla Cruz, 2013). In order to ensure correct understanding, communicators may guide the audience by means of linguistic or expressive choices, i.e. style.

Within relevance-theoretic pragmatics stylistic choices are seen as resulting from the communicator's willingness to be optimally relevant and assist comprehension (Sperber \& Wilson, 1986/1995, p. 219; Trotter, 1992, p. 11). The presumption of optimal relevance that every utterance communicates entails that the utterance will be worth the audience's effort to process it and that it is worded in the most effort-saving way, depending on the speaker's abilities and preferences (Sperber \& Wilson, 1995, p. 270). ${ }^{5}$ Indeed, speakers always make decisions on issues such as the structure or level of

\footnotetext{
${ }^{5}$ The notion of 'abilities' refers to the cognitive skills and capabilities underlying linguistic performance, while that of 'preferences' alludes to a variety of goals, such as complying with norms of politeness or norms dictating the type or amount of information to impart, to whom, how, when and where to present it, etc. (Mazzarella, 2013, pp. 33-35).
} 
formality of their contributions and take advantage of the repertoire of their language in order to assist the audience in their interpretative tasks.

In (1) above, interrogative syntax, a conventionalised formula ('can/could you + verb') and the illocutionary force indicating device (Levinson, 1983) 'please' favour a requestive interpretation and rule out an interpretation as a question about the hearer's physical abilities. Exclamative syntax and the structure 'adjective + noun' facilitate an interpretation of (2) as a congratulation -provided the appropriate paralanguage accompanies it. Quite similarly, a structure such as 'I like' followed by a direct object contributes to the interpretation of (3) as a compliment (Wolfson \& Manes, 1980; Manes \& Wolfson, 1981). In the case of (4), the occurrence of 'sorry' renders the apology interpretation almost automatic. Had the speaker wanted to avoid sounding insincere or felt that a more indirect formulation like (8) could be misinterpreted, she could also have resorted to an explicit performative:

(10)I apologise for being late to class.

Although probably costlier in terms of processing effort, alternative, more verbose formulations like (5-8) often give the audience evidence of the speakers' intention to communicate weak implicatures about, for example, how she treats them or their social relationship (Sperber \& Wilson, 1986/1995). Derivation of those implicatures involves additional, beneficial cognitive effects (Escandell Vidal, 1998) of a social or behavioural nature (Jary, 2013; see also Haugh, 2014), which could not be obtained by means 
of other stylistic choices. Indeed, more elaborate and verbose formulations sometimes get marked as opposed to expected, default ones -which would be unmarked- and give the audience reason to suspect the speaker's intention to make (more) manifest assumptions about her considerateness or politeness (Jary, 1998, p. 9).

Relevance theorists have extensively shown that speakers assist the construction of interpretative hypotheses by means of a rich variety of linguistic resources. For instance, discourse markers indicate the relationships between specific propositions; their procedural meaning steers mental computations in one direction or another by imposing constraints on the type of inferential process needed (Blakemore, 1987, 2002; Jucker, 1993; Moeschler, 1993; Wilson \& Sperber, 1993; Rouchota, 1995).

Accordingly, a marker like 'so' encodes the instruction that two propositions must be connected by a relation of cause and effect: ${ }^{6}$

(11)Mark came to Seville. So he visited the cathedral and the Alcázar. Attitudinal adverbials (e.g. 'happily', 'sadly', 'unfortunately', etc.), interjections (e.g. 'oh!', 'wow!', etc.), intonation and paralanguage help infer the speaker's attitude towards the proposition expressed. While intonation and paralanguage have been argued to be purely procedural elements (Imai, 1998; Wilson \& Wharton, 2006; Wharton, 2009), attitudinal adverbials have been claimed to encode a conceptual content, even if it does

\footnotetext{
${ }^{6}$ According to Carston (2016), the various contributions on connectives or discourse markers made after Blakemore's $(1987,2002)$ influential work may be considered the first stage in the development of the notion of procedural meaning.
} 
not contribute to the lower-level explicature of an utterance, but to its higher-level explicature (Ifantidou, 1992). Interjections would make up a hybrid category that includes elements that may be placed along a cline ranging from purely procedural elements to more conceptual ones (Wharton, 2003, 2009): ${ }^{7}$

(12) Unfortunately, Mark could not come to Seville this year.

(13) Wow! Mark has come to Seville.

Expressive possibilities enable speakers to reformulate utterances with a view to ensuring correct understanding. Reformulations have been argued to constrain interpretative routes and enable exploration of the encyclopaedic entries of lexical items (Blakemore, 1992, 1993, 1994): ${ }^{8}$

(14) Mark visited the Alcázar in Seville. In other words, he visited the oldest inhabited royal residence in Europe.

Concerning presentation of information, relevance theorists have also argued that the so-called illocutionary adverbials (e.g. 'frankly', 'seriously', etc.), evidential adverbials (e.g. 'obviously', 'evidently', 'clearly', etc.), hearsay adverbials (e.g. 'allegedly', 'reportedly', etc.) and some parenthetical expressions (e.g. 'they say', 'I hear', etc.) indicate possession or lack of supportive evidence for information. These elements show the informer's different degrees of commitment to the proposition expressed or

\footnotetext{
${ }^{7}$ See Padilla Cruz (2009) for comments on Wharton's $(2003,2009)$ relevance-theoretic analysis of interjections. The relevance-theoretic analyses of elements contributing to attitudinal descriptions are part of the second stage in the development of the notion of procedural meaning (Carston 2016).

${ }^{8}$ For a different view and criticism, see Culpeper (1994).
} 
whether the information dispensed is considered true, false, reliable or in need of further evidence (Ifantidou, 1992, 1993, 2001; Wilson \& Sperber, 1993; Wilson, 1999):

(15)Frankly, Mark visited the Alcázar in Seville.

(16)Clearly, Mark enjoyed the Alcázar.

(17) Allegedly, Mark came to Seville and visited the Alcázar.

(18)a. I hear that Mark did not enjoy the Alcázar.

b. Mark did not enjoy the Alcázar, I hear.

c. Mark, I hear, did not enjoy the Alcázar.

Similar functions are fulfilled by the indicative mood (9a), the various modal verbs (9b-9d) and the reporting verbs (9e-9f). In Japanese, the utterance-final hearsay particle '-tte' is employed with the same purposes (Itani, 1994, 1998), while in Sissala 'ré' is normally inserted in reported speech or thought, or after speech-act and propositional-attitude verbs corresponding to 'think', 'believe' or 'know' (Blass, 1989, 1990). English and Spanish also resort to past participles that seem to work similarly. In a genre like journalism, where professional ethics encourages objective presentation of facts, clear indication of the source(s) of evidence and unambiguous reference to the veracity of information (Stovall, 2004; Meyers, 2010; Rich, 2015), headlines often attempt to draw readers' attention with texts like these:

(19) Brother of alleged Holly Bobo killer arrested for disposing of evidence. (www.mydailynews.com 19/09/2014) 
(20)Cops release images of waitress's alleged killer.

(www.kaieteurnewsonline.com 7/09/2014)

(21)Boy suspected kidnapper dead after Colorado hostage standoff. (www.reuters.com 5/08/2014)

(22)Update: Suspected kidnapper arrested after crashing car. (www.racinecontyeye.com 22/07/2014)

(23)Detenido el supuesto homicida de una mujer en un coto en Coria. (Sevilla) (www.lavanguardia.com 22/09/2014) Suspected killer of woman in reserve in Coria (Seville) arrested. (24)El supuesto homicida de El Atazar ahogó y acuchilló a su exmujer. (www.elmundo.com 9/08/2011) Suspected El Atazar killer choked and stabbed ex-wife. (25)Alaya cifra en 855 millones el presunto fraude de los ERE en Andalucía (www.lasexta.com 15/08/2014) Judge Alaya values presumed ERE fraud in Andalusia in 855 millions. The English past participles 'alleged' and 'suspected' and the Spanish equivalents 'supuesto' and 'presunto' in these examples do not denote any temporary, accidental or permanent feature or state of the referent of the nouns they accompany, so they cannot be regarded as proper modifying adjectives. Rather, they suggest that the individuals referred to as 'killers' or 'kidnapper', and the action labelled 'fraud', are not yet to be definitely considered or believed as such at a particular time, as each of them might still be under judicial investigation or in need of such investigation. In fact, 
in countries like Spain, laws seek to guarantee, protect and respect individuals' right to a presumption of innocence, so potential criminals and crimes must not be properly regarded as such until enough evidence is found, adduced or provided by witnesses or investigation, and the court or judge announces a sentence. These participles hint that the referents of the pre-modified nouns could be referred to in a particular way or attributed specific properties -being a killer or kidnapper, or fraudulence- in the (near) future as a result of discovery of subsequent supporting evidence which, at the time of writing, is still non-existent or unconfirmed. Participial adjectives are past participles that appear as adnominal modifiers of nouns (Huddleston, 1988, 1993; Greenbaum and Quirk, 1993). Prototypical participial adjectives denote qualities or states of the modified nouns, so they are included as members of the category of adjectives. Like other grammatical categories incorporating lexical items from other categories, that of adjectives is an open one which, in addition to some adverbs and nouns modifying nominal heads, also groups de-verbal items like present and past participles.

Clearly, the past participles above (19-25) do not work as proper participial adjectives. Not only do they not denote qualities or states of a noun, but also they do not exhibit some of the features characterising adjectives and participial adjectives. 


\section{Properties of prototypical participial adjectives}

Many past participles in English or Spanish have adjectival functions and share some of the general properties characteristic of central or core adjectives (Huddleston, 1988, pp. 108-110; Haegeman \& Guéron, 1999, pp. 56-57, 71-72; Collins \& Hollo, 2000, pp. 80-81; Börjars \& Burridge, 2001, pp. 64-65):

a) Occurrence in adnominal positions either before the head noun and after the determiner (attributive position), as in English, or after the head noun (postpositive position), as in Spanish: ${ }^{9}$

(26) a. A broken chair.

b. Una silla rota.

(27)a. The worried person.

b. La persona preocupada.

(28)a. The greatest record broken.

b. El mayor record (jamás) batido.

b) Occurrence in predicative position as subject complement in attributive sentences (29) or as object complement (30):

(29) a. The chair is broken.

b. La silla está rota.

(30) a. He considered the man worried.

\footnotetext{
${ }^{9}$ While in Spanish this seems to be the average or default position for adjectives, in English this position is restricted to adjectives ending in '-able' or '-ible' when the head noun is modified by another adjective in the superlative or other modifiers.
} 
b. Consideró al hombre preocupado.

c) Pre-modification by intensifiers:

(31)a. He was very worried.

b. (Él) Estaba muy preocupado.

c. The chair was utterly destroyed.

d. La silla estaba completamente destrozada.

d) Gradability, i.e. comparative and superlative forms:

(32)a. He was more shocked than surprised.

b. (Él) Estaba más impactado que sorprendido.

(33)a. He was the most surprised person in the room.

b. (Él) Era la persona más sorprendida de la sala.

When used attributively, participial adjectives usually have a passive meaning that can be captured by an equivalent defining relative clause:

(34)a. The offended man > The man who/that was offended.

b. El hombre ofendido > El hombre que ha sido ofendido.

c. Lost property $>$ The property that has been lost.

d. Propiedad perdida > La propiedad que ha sido perdida.

The passive reading, nevertheless, is ruled out when the corresponding verb is intransitive:

(35)a. The departed train > The train that (has/had) departed.

b. El difunto marido > El marido que ha fallecido.

c. The escaped prisoner $>$ The prisoner who (has/had) escaped.

d. El prisionero huido > El prisionero que ha huido. 
Predicative position, in contrast, is only permitted for some participles:

(36) a. The curtains are faded > The curtains have faded.

b. Las cortinas están desteñidas > Las cortinas han desteñido.

c. He is now retired $>$ He has now retired.

d. (Él) Ahora está jubilado > (Él) Ahora se ha jubilado.

Like prototypical adjectives, participial adjectives contribute to the proposition expressed. Replacement with another participle or adjective changes sentence meaning. Replacement with a defining relative clause does not alter the propositional content, although the resulting sentence differs in terms of syntactic structure (34). In relevance-theoretic terms, participial adjectives can therefore be said to encode a conceptual content that contributes to the lower-level explicatures of utterances and affects their truth conditions (Sperber \& Wilson, 1986/1995; Wilson \& Sperber, 2002, 2004).

Despite their attributive position, the adjectival status of the participial adjectives in the headlines in the previous section (19-25) is dubious. Neither can they be intensified (37), nor do they seem to have comparative or superlative forms (38-39):

(37)a. *The brother of very alleged Holly Bobo killer.

b. *Very suspected kidnapper arrested. ${ }^{10}$

c. *Detenido el muy supuesto homicida.

\footnotetext{
${ }^{10}$ Note, however, that these participial adjectives can be modified by adverbs such as 'widely'.
} 
d. *El muy presunto fraude de los ERE.

(38) a. *He was more alleged than suspected.

b. *(Él) Era más presunto que supuesto

(39) a. *He was the most alleged killer (in the room).

b. *(Él) era el homicida más supuesto (de la sala).

Also, placing those participles in predicative position yields a bizarre sentence:

(40) a. *The killer is alleged.

b. *El homicida es presunto.

Furthermore, although the corresponding verbs of the English participles are transitive and, consequently, would allow for a passive transformation, substitution with a passive form results in an odd sentence:

(41) a. *The killer who/that is/was alleged.

b. *El homicida que es/fue presunto.

Even if 'allege' is transitive, the person alleged to have done something is not its direct object, so a sentence like (42) would be ungrammatical: (42)*The police alleged him.

Passivisation could only be licensed if the participles were followed or complemented by an infinitival clause:

(43) The man who/that is/was alleged/suspected to have committed three crimes.

Substitution of the participles of the Spanish verbs 'suponer' or 'presumir' with a passive form would not be very common or natural either. Despite a 
certain preference for impersonal structures with 'se' as a subject slot-filler -'se supone', 'se presume'- if the Spanish participles of these verbs were substituted with impersonal forms, they would subcategorise a finite complement clause introduced by the complementiser 'que', which functions as their direct object: (44)El hombre que se supone/presume que ha cometido tres crímenes.

Failure to share the properties of prototypical participial adjectives suggests that the past participles analysed in this work may constitute a sub-type in their own right specialised for fulfilling a specific function: informing about the communicator's evidence when making an assertion. In this respect, these past participles work as evidentials and their insertion in utterances is intended to achieve specific perlocutionary effects: whether the audience should take with a pinch of salt, question or not yet completely believe a claim or assertion made because of lack of the pertinent evidence (Wilson, 2012; Piskorska, 2016).

\section{On the evidential function of some past participles}

Some modals verbs (e.g. 'may', 'must', 'should'), adjectives (e.g. 'able', 'possible') and clausal elements (e.g. 'I think', 'they say') have often been considered devices to express modality (Palmer, 1986, 2001). Modality must be distinguished from verbal features such as mood, tense and aspect, 
which are realised by inflections in many languages, because "[...] it does not refer directly to any characteristic of the event $[\ldots]$ " presented in a proposition, “[...] but simply to the status of the proposition" (Palmer, 2001, p. 1). As Huddleston (1993, pp. 165-166) states, modality is “[...] a rather broad term for $[\ldots]$ a category of meaning".

Traditionally, grammarians have differentiated two kinds of modality:

(i) Epistemic -from the Ancient Greek word for 'knowledge' (Huddleston, 1993, p. 166)- which is related to the status of a proposition as true, false, probable, possible, necessary, etc., depending on what the speaker knows. This kind of modality is also known as extrinsic because there is a "[...] human judgement of what is or is not likely to happen" and seen as more objective (Greenbaum \& Quirk, 1993, p. 60).

(ii) Deontic-from the Ancient Greek word alluding to the notion of 'binding'- which has to do with how the speaker presents an action, i.e. as obligatory, permitted, advisable, etc. (Huddleston, 1993, pp. 167-168). This kind of modality is also labelled intrinsic because some "[...] human control over events" is involved and is seen as more subjective (Greenbaum \& Quirk, 1993, p. 60).

The so-called epistemic modals have more recently been re-analysed as conveying information about the speaker's attitude(s) towards the propositional content communicated. Among those attitudes are, for 
instance, strong (dis)belief in, (un)certainty about or (non-)commitment to the truth of the propositional content of an assertion.

Modality must be distinguished from evidentiality, a linguistic category “[...] whose primary meaning is source of information" (Aikhenvald, 2004, p. 3) and refers to the speaker's indication of her degree of commitment to a claim depending on available evidence (Crystal, 1991, p. 127). Such indication is motivated by the source(s) of the information taken into account when communicating (Dendale \& Tasmowski, 2001), which may be perceptual or epistemological (Cornillie, 2007, p. 45): visual, non-visual but directly perceived, informed by perceptual clues, assumed via testimony, etc. (Aikhenvald, 2004). Since the source(s) of information may be more or less reliable or trustworthy (Matthews, 2007), evidentiality is the indication of the origin(s) of the knowledge on which the speaker bases her assertion(s) about (a) particular state(s) of affairs, or of the compatibility of that/those state(s) of affairs with her own universe of beliefs (Nuyts, 2006, p. 10).

Stylistic choices lead to optimally relevant interpretations, but those interpretations need not be reliable or credible. In effect, informers do not always behave benevolently because they may attempt to deceive or misguide the audience, or competently because they may lack adequate evidence when imparting information. In relevance-theoretic pragmatics, linguistic expressions like evidential and hearsay adverbials, parenthetical elements or hearsay particles have been analysed as indicators of the sort of 
evidence communicators rely on and are subsumed under the umbrella term evidentials (Ifantidou, 2001). Evidentials have been claimed to indicate whether the audience should believe, discredit or be cautious about dispensed information. They have been argued to trigger the construction of (more) sophisticated higher-level explicatures that include some indication of the speaker's degree of (un)certainty about the communicated content or the evidence she relies on when making an assertion:

(45)a. The speaker (strongly/firmly) believes that $p$.

b. The speaker is (very) certain/uncertain that $p$.

Relevance theorists posit that the human mind has developed a complex set of specialised mechanisms for monitoring the believability and reliability of informers -i.e. the source(s) of information- and the information that they supply -i.e. the content itself. Those mechanisms take into account a variety of internal and external factors that determine whether a person and the information she provides should be trusted (Origgi, 2013) and trigger an attitude of epistemic vigilance (Mascaro \& Sperber, 2009; Sperber et al., 2010). Following Wilson $(2012,2016)$, the past participles on which this chapter focuses could be considered, like other evidentials, to fulfil an important function: activating and assisting epistemic vigilance mechanisms in their assessments of the trustworthiness of informers and information. Accordingly, the participles in question could have become specialised for targeting epistemic vigilance mechanisms by alerting them to the likely veracity or falsity of claims due to lack of evidence. 


\subsection{Evidentials and epistemic vigilance}

Informers and information deserve trust to a greater or lesser extent. People have epistemic confidence in other individuals and assign or deprive them of epistemic trustworthiness (Fricker, 2007). Research in developmental psychology has revealed that between the ages of two and three, children develop a sensibility towards individuals and what they say. As a result, children can determine the veracity or falsity of information, can contradict or correct assertions they consider false or questionable, and seem to prefer individuals whom they regard as benevolent and competent on the basis of past personal experiences and what other people tell them about those individuals (Clément et al., 2004; Koenig \& Harris, 2007; Heyman, 2008; Corriveau \& Harris, 2009). These findings lend support to the idea that the human mind comprises a cluster of varied mechanisms specialised for discriminating the trustworthiness or reliability of informants and of information.

Epistemic vigilance mechanisms take into account a variety of sources of trust (Origgi, 2013, pp. 227-233) which cause an individual to think of others and what they claim or assert in a particular way:

a. Beliefs and prejudices about an informer's reliability accrued from prior exchanges.

b. The relevance of what is said. 
c. Internalised social norms of complying with authorities or experts in some domain or issues.

d. The informer's socially distributed reputation as an informant.

e. Signals that unveil knowledge/ignorance about or possession/lack of evidence for specific issues: hesitation, stuttering, odd syntax, rephrasing, difficulties at finding appropriate words, or particles, adverbials and clausal elements like those presented above.

f. Emotional reactions biasing the conclusions derived about the informer: affect, anger, wrath, etc.

g. Moral commitments determining whether the hearer should actually think of the informer in a particular way.

These sources cause epistemic vigilance mechanisms to trigger a certain alertness or critical stance towards informers and information (Sperber et al., 2010, p. 363). These mechanisms do not automatically generate distrust, but a critical attitude that differs from blind, naïve and uncritical trust (Sperber et al. 2010; Mercier \& Sperber, 2011; Sperber \& Mercier, 2012). Such an attitude empowers individuals to move from a position of indiscriminate trust, in which credibility is almost automatically given to beliefs or states of affairs, or another position of gullible trust, where information is believed even if it contradicts previous personal observations, to one of sceptical trust (Clément et al., 2004, pp. 361-363). In this last position, information and the implications following from it are not uncritically believed, above all if the informer has proved unreliable beforehand or the information is 
perceived not to have been duly supported by pertinent evidence. In so doing, vigilance mechanisms safeguard individuals against some of the possible risks of communication: deception and misinformation.

Epistemic vigilance mechanisms may not always be effective, as they may be weakly activated (Michaelian, 2013, p. 42). Their default state, according to Sperber (2013, p. 64), is one of moderate activation. However, individuals raise their activation "[...] by a closer inspection of data, sometimes interrogating [themselves] about the sources of [their] trust or distrust, and sometimes by refining [their] cognitive heuristics" (Origgi, 2013 , p. 224). When vigilance is raised, individuals become actively vigilant and their alertness to the quality of information increases. Active or strong vigilance involves (Origgi, 2013, p. 226-227):

i. External vigilance or 'looking outward', so to say, in order to become aware of the operating cultural norms and contextual elements (e.g. preceding discourse, paralanguage, elements in the communicative situation, etc.) that determine allocation or deprival of trust to information.

ii. Internal vigilance or 'looking inward', so to say, by scrutinising the interpretative steps taken, the cognitive tasks performed, the beliefs used when contextualising information and the conclusions reached. Raised vigilance is fundamental for maintaining a necessary critical stance on the biases, social pressures and prejudices that might affect thinking. 
Indeed, an actively vigilant attitude facilitates awareness of the reasons why trust is allocated to interlocutors and information.

Informants may also contribute to the activation of vigilance mechanisms or assist them in their decisions about whether to believe or discredit information and/or informers through stylistic decisions. In addition to the elements exemplified in Section 3, relevance theorists have also recently paid attention to some quotatives in languages like Estonian or Sissala, which are exploited in narratives and argumentation in order to aid vigilance mechanisms in their tasks (Unger, 2016). In fact, in the case of argumentation more specifically, convincing the audience of some fallacies may be a matter of bypassing the filters of vigilance mechanisms (Oswald, 2011, 2016). ${ }^{11}$

The past participles discussed in this chapter seem to fulfil a similar assistive function for epistemic vigilance mechanisms. In a similar way to hearsay particles, hearsay and evidential adverbials, parenthetical expressions and some main verbs (Ifantidou, 1992, 1993, 2001; Itani, 1994, 1998; Wilson \& Sperber, 1993; Wilson, 1999), those participles indicate whether an informer has (sound) evidence to consider that a part of a claim she makes actually holds true at the moment of speaking. In other words, those participles indicate that the way in which an event, state of affairs or

\footnotetext{
${ }^{11}$ In some types of jokes, vigilance mechanisms would detect if the comprehension module has been fooled into granting plausibility to an interpretative hypothesis that appears optimally relevant but is inadequate (Padilla Cruz, 2012), while in puns vigilance mechanisms would detect that ambiguous words or fragments are not correctly disambiguated (Padilla Cruz, 2015).
} 
individual are labelled, characterised or alluded to in an assertion should not necessarily be taken for granted. Thus, those participles additionally prevent the audience from giving credibility to implications likely to be derived from the claim made at the time of speaking.

Consider assertions or claims like (46) and (48), from which implications like (47) and (49) may respectively be drawn:

(46) Suspected woman kidnapper arrested after car crash.

(47)a. Someone will be sentenced to prison.

b. Someone might have to pay compensation.

(48) Judge values presumed fraud in 855 millions.

(49)a. Someone is a robber.

b. Someone will be sent to prison.

c. Someone will have to return stolen money.

d. Someone should not have public responsibilities.

The participles in (46) and (48) unveil that the informer has not accrued the requisite evidence to be certain at the time of speaking about the veracity of a likely state of affairs mentioned in those assertions or claims -namely, that a particular person has actually kidnapped a woman or that someone has really committed monetary fraud- or that the evidence for regarding someone or some events in a particular way is not completely reliable. Thus, these participles caution the audience against deriving and crediting certain implications $(47,49)$. Those participles alert vigilance mechanisms to the 
potential (im)plausibility of a state of affairs mentioned in a claim or assertion, as well as to its likelihood to be (un)trustworthy.

The morpho-syntactic peculiarities of those participles suggest that, in contrast to standard pre-modifying past participles, languages like English or Spanish might have dedicated them to activate epistemic vigilance mechanisms or raise the activation of these mechanisms in case they are weakly activated or 'dormant', so to say. This is essential for these mechanisms to detect informers' trustworthiness or certainty about claims or assertions they make. Raised activation of these mechanisms results in external vigilance, which prompts an audience to search for additional evidence that backs them up in believing or discrediting a state(s) of affairs alluded to in a claim or assertion, or wait for the necessary evidence to be adduced.

Due to these functions, past participles like English 'alleged' or 'suspected' and Spanish 'presunto' or 'supuesto' could be termed evidential participles and be described as 'alerters' of epistemic vigilance mechanisms to the credibility or likelihood of a state of affairs mentioned in a claim or assertion. Evidential participles indicate whether the audience are entitled to believe, discredit or take with a grain of salt a part or fragment of what an informant says, and to draw and believe possible implications ensuing from it. Even though evidential participles share the functions described above with other evidential expressions, their pre-modifying position right before the modified head noun seems to suggest that they work slightly differently. 


\subsection{What evidential participles communicate}

One of the most significant contributions of relevance-theoretic pragmatics has been its distinction between conceptual and procedural expressions (Blakemore, 1987, 1992, 2004; Wilson and Sperber, 1993, 2002a, 2004; Carston, 2016; Wilson, 2016). While the former encode representations that may become constituents of lower-level explicatures and, therefore, affect the truth-conditional content of utterances, the latter encode instructions steering processing and comprehension. Typical examples of purely conceptual expressions are nouns, verbs, adjectives or adverbs, while typical examples of purely procedural expressions are discourse markers.

The conceptual-procedural distinction is not a clear-cut one, nonetheless: not all conceptual expressions contribute to lower-level explicatures and, therefore, to the truth-conditional content of utterances, and some procedures may be encoded by expressions with a conceptual nature (Wilson \& Sperber, 1993). There are conceptual expressions that contribute to higher-level explicatures by constraining their construction; for instance, illocutionary, attitudinal and evidential adverbials. ${ }^{12}$ On the other hand, some procedural expressions may encode some sort of conceptual content, even if schematic; for example, personal pronouns.

\footnotetext{
${ }^{12}$ See Ifantidou $(1992,1993)$ for a discussion of different tests for truth-conditionality to these expressions, such as insertion in conditional or disjunctive structures.
} 
Evidential participles seem to be conceptual and to contribute to the proposition expressed. If they are removed or replaced with an adjective or another past participle, the meaning of the resulting assertion and its truth conditions change:

(50)a. Alleged/Suspected killer arrested.

b. Killer arrested.

c. Handsome killer arrested.

(51)a. Presunto/supuesto homicida arrestado.

b. Homicida arrestado.

c. Apuesto homicida arrestado.

In the first sentence of these two examples, the speaker claims that someone who must (still) be suspected to be a killer due to lack of contrary evidence has been arrested. In the second sentence, the speaker asserts that a person who definitely is a killer has been arrested. In the third sentence, the speaker informs about the arrest of a killer who is characterised by a particular feature. The evidential participle, therefore, contributes to the lower-level explicature of the utterance.

Evidential participles have hearsay adverbial counterparts like English 'allegedly' and 'supposedly' (52) and Spanish 'supuestamente' and 'presuntamente' (53). These adverbials, which are respectively derived from the transitive verbs 'to allege' and 'to suppose' in the case of English, and from 'suponer' and 'presumir' in that of Spanish, may be placed in distinct positions. Note that, if the corresponding English verb is passivised, it 
subcategorises an infinitival clause (54). Spanish, in contrast, prefers an impersonal form followed by a finite complement clause that is introduced by the complementiser 'que' and functions as the direct object (55):

(52)a. Allegedly, the killer was sent to prison.

b. The killer was, allegedly, sent to prison.

c. The killer was sent to prison, allegedly.

(53)a. Supuestamente, el homicida fue enviado a prisión.

b. El homicida fue, supuestamente, enviado a prisión.

c. El homicida fue enviado a prisión, supuestamente.

(54) The killer is alleged to have been sent to prison.

(55) Su supone que el homicida fue enviado a prisión.

However, what the speaker reports by means of assertions containing hearsay adverbials $(52,53)$ differs from what she claims with assertions containing evidential participles:

(56)a. The alleged killer was sent to prison.

b. El supuesto homicida fue enviado a prisión.

In (52) and (53) the speaker communicates her uncertainty about or lack of strong evidence concerning the fact that someone, who can definitely be regarded as a killer, was actually sent to prison. In (56) the speaker asserts that someone, who cannot yet be considered a killer because of lack of backing evidence, was certainly imprisoned. Therefore, while hearsay adverbials indicate the weakness of the informer's belief in, certainty about or commitment to a whole proposition, evidential participles only unveil the 
weakness of her belief in, certainty about or commitment to a state of affairs alluded to in an assertion by means of one of its constituents: a noun phrase. Obviously, the hearer of an utterance like (56) may think that the speaker, upon using the evidential participle, also intends to subtly invite an implicature to the effect that she hopes or expects -or that it is hoped or expected- that confirming evidence will come to light.

The fact that hearsay adverbials and evidential participles affect what an informer claims in differing ways is attested by distinct tests. Firstly, hearsay adverbials are not properly integrated into the syntax of an assertion or claim. They are separated from it by a pause in speech and a comma in writing, thus constituting an independent tone-unit. Moreover, they may be freely placed before or after the assertion/claim, or in the middle of it. However, evidential participles occupy a fixed position as pre-modifiers of a nominal head.

Secondly, substitution of hearsay adverbials by their corresponding verbs followed by a clause acting as direct object is possible. For evidential participles to be replaced by their corresponding verbs, it would be necessary to use a defining relative clause. In English, that clause would have a passive verb that in turn subcategorises an infinitival clause. In Spanish, the verb of that clause would be an impersonal form that subcategorises a finite complement clause introduced by the complementiser 'que'. Additionally, for the defining relative clause to be licensed in 
Spanish, the initial noun -e.g. 'killer'- needs substituting with another one e.g. 'person', 'man':

(57)a. The man who is alleged/supposed to be the/a killer has been sent to prison.

b. El hombre que se supone/cree que es un homicida ha sido enviado a prisión.

These formal and transformational differences reveal that the scope of hearsay adverbials is the whole asserted proposition, whereas that of evidential participles is only a part of the asserted proposition. Therefore, hearsay adverbials instruct epistemic vigilance mechanisms to be cautious about the veracity of a whole proposition, while evidential participles alert those mechanisms to the likely untruthfulness of a state of affairs alluded to in an assertion/claim.

\section{Conclusion}

Comprehension is assisted by a number of linguistic and paralinguistic elements that include discourse markers, attitudinal adverbials, interjections or intonation. Languages also count on other devices that enable informers to warn about the believability of information: hearsay particles and adverbials, evidential adverbials, some main verbs and parenthetical 
expressions. Generally labelled evidentials, these devices indicate informers' benevolence and level of competence in some domain or issue. This chapter has looked into a group of past participles which, unlike prototypical ones, do not have adjectival functions but work as evidentials. Evidential past participles, as they are termed in this chapter, encode a conceptual content that contributes to the truth-conditional content of the proposition where they appear, but they also encode procedural meaning. Like hearsay adverbials, evidential participles have been argued to target the cluster of mechanisms responsible for an attitude of epistemic vigilance. They enact the activation of those mechanisms or increase their activation, which results in external vigilance of preceding or upcoming discourse. Active vigilance is essential for avoiding (indiscriminate) gullibility and adopting the sceptical trust indispensable for the formation and fixation of accurate beliefs.

While hearsay adverbials take within their scope the whole proposition they are appended to, the scope of evidential participles is more limited. It only is a fragment of an asserted proposition: a nominal head. This means that evidential participles alert vigilance mechanisms to the fact that the referent of a nominal expression alluded to in the asserted proposition should not be taken as responsible for a particular state of affairs or to the fact that the state of affairs referred to by means of a noun may not actually hold as true at the moment when an assertion is made because of lack of adequate evidence or unreliability of available evidence. As a result, the audience is 
not entitled to derive and regard as true some implications that may follow from the assertion made. Thus, evidential participles suggest that it would only be in the (near) future, and provided that reliable evidence is adduced, that a nominal referent could definitely be considered responsible for a particular state of affairs, or a state of affairs alluded to could be believed to actually hold.

This function could also intertwine with another one: marking interpretive use. Evidential participles would somehow show that the noun with which they occur is not descriptively used or should not be thus used at the moment of speaking or writing. If it was, its referent could in effect be considered responsible for the state of affairs in question, or the state of affairs alluded to through that noun would actually hold. What evidential participles indicate is that the nominal referent is or will be considered in a particular manner by certain people if certain circumstances eventually or ultimately applied. To put it differently, evidential participles indicate that the referent is considered or believed by certain people to actually have certain characteristics or to likely have them in the (near) future provided certain circumstances applied. The activation of vigilance mechanisms surely depends on this marking of interpretive use, a dependence that future research should certainly study in detail.

\section{References}


Aikhenvald, Alexandra. 2004. Evidentiality. Oxford: Oxford University Press.

Arundale, Robert B. 2006. "Face as Relational and Interactional: A Communication Framework for Research on Face, Facework and Politeness". Journal of Politeness Research. Language, Behaviour, Culture 2/2: 193-216.

Austin, John. 1962. How to Do Things with Words. Oxford: Oxford University Press.

Blakemore, Diane. 1987. Semantic Constraints on Relevance. Oxford: Blackwell.

Blakemore, Diane. 1992. Understanding Utterances. Oxford: Blackwell.

Blakemore, Diane. 1993. “The Relevance of Reformulations”. Language and Literature 2: 101-120.

Blakemore, Diane. 1994. "Relevance, Poetic Effects and Social Goals: A Reply to Culpeper". Language and Literature 3: 49-59.

Blakemore, Diane. 2004. Relevance and Linguistic Meaning. The Semantics and Pragmatics of Discourse Markers. Cambridge: Cambridge University Press.

Blass, Regina. 1989. "Grammaticalisation of Interpretive Use: The Case of ré in Sissala". Lingua 79: 299-326.

Blass, Regina. 1990. Relevance Relations in Discourse. Cambridge: Cambridge University Press. 
Börjars, Kersti and Kate Burridge. 2001. Introducing English Grammar. London: Arnold.

Brown, Penelope and Stephen C. Levinson. 1987. Politeness. Some Universals in Language Usage. Cambridge: Cambridge University Press.

Carston, Robyn. 2002. Thoughts and Utterances. The Pragmatics of Explicit Communication. Oxford: Blackwell.

Carston, Robyn. 2016. “The Heterogeneity of Procedural Meaning”. Lingua 175-176: 154-166.

Clément, Fabrice, Melissa Koenig and Paul Harris. 2004. “The Ontogeny of Trust". Mind \& Language 19/4: 360-379.

Collins, Peter and Carmella Hollo. 2000. English Grammar: An Introduction. Basingstoke: Palgrave Macmillan.

Cornillie, Bert. 2007. Evidentiality and Epistemic Modality in Spanish (Semi-)Auxiliaries: A Cognitive-functional Approach. Berlin: Mouton de Gruyter.

Corriveau, Kathleen and Paul Harris. 2009. "Preschoolers Continue to Trust a More Accurate Informant 1 Week after Exposure to Accuracy Information”. Developmental Science 12/1: 188-193.

Crystal, David. 1991. A Dictionary of Linguistics and Phonetics. Oxford: Blackwell.

Culpeper, Jonathan. 1994. "Why Relevance Theory Does Not Explain 'The Relevance of Reformulations"'. Language and Literature 3: 43-48. 
Dendale, Patrick and Liliane Tasmowski. 2001. "Introduction: Evidentiality and Related Notions". Journal of Pragmatics 33/3: 339-348.

Escandell Vidal, Victoria. 1998. "Politeness: A Relevant Issue for Relevance Theory”. Revista Alicantina de Estudios Ingleses 11: 45-57.

Fricker, Miranda. 2007. Epistemic Injustice. Power \& the Ethics of Knowing. Oxford: Oxford University Press.

Greenbaum, Sidney and Randolph Quirk. 1993. A Student's Grammar of the English Language. London: Longman.

Grice, Herbert P. "Logic and Conversation”. 1975. In Syntax and Semantics. Vol. 3: Speech Acts, ed. by Peter Cole and Jerry L. Morgan, 41-59. New York: Academic Press.

Haegeman, Liliane M. V. and Jacqueline Guéron. 1999. English Grammar: A Generative Perspective. Oxford: Blackwell.

Haugh, Michael. 2014. Im/Politeness Implicatures. Berlin: Mouton de Gruyter.

Heyman, Gail D. 2008. “Children’s Critical Thinking when Learning from Others". Current Directions in Psychological Science 17/5: 344-347.

Holmes, Janet and Dorothy F. Brown. 1987. "Teachers and Students Learning about Compliments". TESOL Quarterly 21: 523-546.

Huddleston, Rodney. 1988. English Grammar: An Outline. Cambridge: Cambridge University Press.

Huddleston, Rodney. 1993. Introduction to the Grammar of English. Cambridge: Cambridge University Press. 
Ifantidou, Elly. 1992. "Sentential Adverbs and Relevance". UCL Working Papers in Linguistics 4: 193-214.

Ifantidou, Elly. "Parentheticals and Relevance". 1993. UCL Working Papers in Linguistics 5: 193-210.

Ifantidou, Elly. 2001. Evidentials and Relevance. Amsterdam: John Benjamins.

Imai, Kunihiko. 1998. "Intonation and Relevance”. In Relevance Theory. Applications and Implications, ed. by Robyn Carston and Seiji Uchida, 69-86. Amsterdam: John Benjamins.

Itani, Reiko. 1994. “A Relevance-based Analysis of Hearsay Particles: Japanese Utterance-final tte". UCL Working Papers in Linguistics 6: $379-400$.

Itani, Reiko. 1998. “A Relevance-based Analysis of Hearsay Particles: With Special Reference to Japanese Sentence-final Particle tte”. In Relevance Theory. Applications and Implications, ed. by Robyn Carston and Seiji Uchida, 47-68. Amsterdam: John Benjamins.

Jary, Mark. 1998. "Relevance Theory and the Communication of Politeness". Journal of Pragmatics 30: 1-19.

Jary, Mark. 2013. "Two Types of Implicatures: Material and Behavioural”. Mind \& Language 28/5: 638-660.

Koenig, Melissa and Paul Harris. 2007. "The Basis of Epistemic Truth: Reliable Testimony or Reliable Sources?" Episteme 4/3: 264-284. 
Levinson, Stephen C. 1983. Pragmatics. Cambridge: Cambridge University Press.

Locher, Miriam A. 2006. "Polite Behaviour within Relational Work: The Discursive Approach to Politeness". Multilingua, Journal of CrossCultural and Interlanguage Communication 25/3: 249-267.

Manes, Joan and Nessa Wolfson. 1981. "The Compliment Formula”. In Conversational Routine. Explorations in Standardized Communication Situations and Prepatterned Speech, ed. by Florian Coulmas, 115-132. The Hague: Mouton.

Marandin, Jean-Marie. 1987. "Des mots et des actions : 'Compliment', 'complimenter' et l'action de complimenter'. Lexique 5: 65-99.

Mascaro, Olivier and Dan Sperber. 2009. "The Moral, Epistemic, and Mindreading Components of Children's Vigilance towards Deception”. Cognition 112/3: 367-380.

Matthews, Peter H. 2007. Oxford Concise Dictionary of Linguistics. $2^{\text {nd }}$ edition. Oxford: Oxford University Press.

Mazzarella, Diana. 2013. “'Optimal Relevance’ as a Pragmatic Criterion: The Role of Epistemic Vigilance”. UCL Working Papers in Linguistics 25: $20-45$.

Mercier, Hugo and Dan Sperber. 2011. "Why Do Humans Reason? Arguments for an Argumentative Theory". Behavioral and Brain Sciences 34/2: 57-111. 
Meyers, Christopher, ed. 2010. Journalism Ethics: A Philosophical Approach. Oxford: Oxford University Press.

Michaelian, Kourken. 2013. “The Evolution of Testimony: Receiver Vigilance, Speaker Honesty and the Reliability of Communication". Episteme 10/1: 37-59.

Norrick, Neal. 1980. “The Speech Act of Complimenting”. In The Nordic Languages and Modern Linguistics, ed. by Even Hovdhaugen, 296-304. Oslo: Universitetsforlaget.

Nuyts, Jan. 2006. “Modality: Overview and Linguistic Issues”. In The Expression of Modality, ed. by William Frawley, 1-26. Berlin: Mouton de Gruyter.

Origgi, Gloria. 2013. "Epistemic Injustice and Epistemic Trust”. Social Epistemology: A Journal of Knowledge, Culture and Policy 26/2: 221235.

Oswald, Steve. 2011. "From Interpretation to Consent: Arguments, Beliefs and Meaning”. Discourse Studies 13/6: 806-814.

Oswald, Steve. 2016. "Rhetoric and Cognition: Pragmatic Constraints on Argument Processing". In Relevance Theory. Recent Development, Current Challenges and Future Directions, ed. by Manuel Padilla Cruz, 261-285. Amsterdam: John Benjamins.

Padilla Cruz, Manuel. 2009. "Towards an Alternative Relevance-theoretic Approach to Interjections". International Review of Pragmatics 1/1: 182206. 
Padilla Cruz, Manuel. 2012. "Epistemic Vigilance, Cautious Optimism and Sophisticated Understanding". Research in Language 10/4: 365-386.

Padilla Cruz, Manuel. 2013. "Understanding and Overcoming Pragmatic

Failure in Intercultural Communication: From Focus on Speakers to

Focus on Hearers". IRAL, International Review of Applied Linguistics in Language Teaching 51/1: 23-54.

Padilla Cruz, Manuel. 2015. "On the Role of Vigilance in the Interpretation of Puns". Humor. International Journal of Humor Research 28/3: 469490.

Palmer, Frank. 1986. Mood and modality. Cambridge: Cambridge University Press.

Palmer, Frank. 2001. Mood and Modality. $2^{\text {nd }}$ edition. Cambridge: Cambridge University Press.

Piskorska, Agnieszka. 2016. "Perlocutionary Effects and Relevance Theory". In Relevance Theory. Recent Developments, Current Challenges and Future Directions, ed. by Manuel Padilla Cruz, 287-305. Amsterdam: John Benjamins.

Rich, Carole. 2015. Writing and Reporting News: A Coaching Method. Boston: Cengage Learning.

Searle, John. 1969. Speech Acts: An Essay in the Philosophy of Language. Cambridge: Cambridge University Press.

Spencer-Oatey, Helen. 2008. Culturally Speaking. Culture, Communication and Politeness. London: Continuum. 
Sperber, Dan. 2013. "Speakers Are Honest because Hearers Are Vigilant. Reply to Kourken Michaelian”. Episteme 10/1: 61-71.

Sperber, Dan and Hugo Mercier. 2012. "Reasoning as a Social

Competence". In Collective Wisdom: Principles and Mechanisms, ed. by Hélène Landemore and Jon Elster, 368-392. Cambridge: Cambridge University Press.

Sperber, Dan, Fabrice Clément, Christophe Heintz, Olivier Mascaro, Hugo Mercier, Gloria Origgi and Deirdre Wilson. 2010. "Epistemic Vigilance". Mind and Language 25/4: 359-393.

Sperber, Dan and Deirdre Wilson. 1995. Relevance. Communication and Cognition. $2^{\text {nd }}$ ed. Oxford: Blackwell.

Stovall, James G. 2004. Journalism: Who, What, When, Where, Why, and How. Boston: Pearson.

Thomas, Jenny. 1995. Meaning in Interaction. An Introduction to Pragmatics. London: Longman.

Unger, Christoph. 2016. "Evidentials, Genre and Epistemic Vigilance". In Relevance Theory. Recent Developments, Current Challenges and Future Directions, ed. by Manuel Padilla Cruz, 239-258. Amsterdam: John Benjamins.

Wharton, Tim. 2003. 'Interjections, Language and the 'Showing-saying' Continuum". Pragmatics and Cognition 11: 39-91.

Wharton, Tim. 2009. Pragmatics and Non-verbal Communication. Cambridge: Cambridge University Press. 
Wilson, Deirdre. 1995. "Is There a Maxim of Truthfulness?” UCL Working Papers in Linguistics 7: 197-212.

Wilson, Deirdre. 2012. "Modality and the Conceptual-procedural Distinction". In Relevance Theory: More than Understanding, ed. by Ewa Wałaszewska and Agnieszka Piskorska, 23-44. Newcastle: Cambridge Scholars Publishing.

Wilson, Deirdre. 2016. "Reassessing the Conceptual-Procedural Distinction”. Lingua 175-176: 5-19.

Wilson, Deirdre and Dan Sperber. 1993. "Linguistic Form and Relevance". Lingua 90/1-2: 1-25.

Wilson, Deirdre and Dan Sperber. 2002a. "Relevance Theory”. UCL Working Papers in Linguistics 14: 249-287.

Wilson, Deirdre and Dan Sperber. 2002b. "Truthfulness and Relevance". Mind 111: 583-632.

Wilson, Deirdre and Dan Sperber.2004. "Relevance Theory”. In The Handbook of Pragmatics, ed. by Larry Horn and Gregory Ward, 607632. Oxford: Blackwell.

Wilson, Deirdre and Tim Wharton. 2006. "Relevance and Prosody". Journal of Pragmatics 38: 1559-1579.

Wolfson, Nessa. 1983. “An Empirically Based Analysis of Complimenting in American English”. In Sociolinguistics and Language Acquisition, ed. by Nessa Wolfson and Eda Judd, 82-95. Rowley: Newbury House. 
Wolfson, Nessa and Joan Manes. 1980. "The Compliment as a Social Strategy". Papers in Linguistics 13: 391-410.

Yus Ramos, Francisco. 1999a. "Towards a Pragmatic Taxonomy of Misunderstandings”. Revista Canaria de Estudios Ingleses 38: 217-239.

Yus Ramos, Francisco. 1999b. "Misunderstandings and Explicit/Implicit Communication". Pragmatics 9: 487-517. 